\title{
The invasive grass genus Nassella in South Africa: A synthesis
}

\author{
Anthony Mapaura ${ }^{\mathrm{a}, *}$, Kim Canavan $^{\mathrm{b}}$, David M. Richardson ${ }^{\mathrm{c}}$, Vincent R. Clark ${ }^{\mathrm{d}}$, \\ Sandy-Lynn Steenhuisen ${ }^{\mathrm{a}}$ \\ a Afromontane Research Unit and Department of Plant Sciences, University of the Free State, Qwaqwa Campus, Phuthaditjhaba 9866, South Africa \\ ${ }^{\mathrm{b}}$ Centre for Biological Control, Department of Entomology and Zoology, Rhodes University, Grahamstown 6140, South Africa

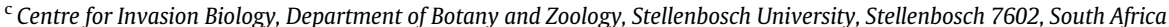 \\ d Afromontane Research Unit and Department of Geography, University of the Free State, Qwaqwa Campus, Phuthaditjhaba 9866, South Africa
}

\section{A R T I C L E I N F O}

\section{Article History:}

Received 21 April 2020

Revised 6 July 2020

Accepted 28 August 2020

Available online $\mathrm{xxx}$

Edited by S Geerts

Keywords:

Biological invasions

Invasive grasses

Nassella neesiana

Nassella tenuissima

Nassella trichotoma

Poaceae

\begin{abstract}
A B S T R A C T
Three species of Nassella have naturalized in South Africa. Nassella trichotoma and $N$. tenuissima are declared weeds under category $1 \mathrm{~b}$ of the National Environmental Management: Biodiversity Act (NEM:BA) and occur mainly in the montane grasslands of the Western and Eastern Cape provinces. Nassella neesiana is not listed in NEM:BA but is naturalized in the Eastern Cape, Western Cape and Free State provinces. Research conducted in the 1970s and 1980s led to vigorous government-funded awareness and control campaigns which ended in 2000. No research on Nassella distribution or control has been undertaken since then. Despite this hiatus, Nassella remains a dangerous genus in southern Africa, given the serious impacts of these species in similar social-ecological systems in Australia and New Zealand. This paper presents a synthesis of available information about Nassella invasions in South Africa and identifies research gaps. It specifically addresses these questions: What identification issues exist? What is the current spatial distribution of Nassella? What is the autecology of the genus? What are the social-ecological impacts of Nassella? What control measures are currently applied and what are their strengths and limitations? What do we know about Nassella distribution and its response to climate change? This paper highlights many knowledge gaps about Nassella, such as the species' current distribution range, field identification and detection difficulties, and the uncoordinated control efforts that require urgent research to inform an effective management response.
\end{abstract}

(c) 2020 SAAB. Published by Elsevier B.V. All rights reserved.

\section{Introduction}

The genus Nassella (Trin.) E. Desv. belongs to the grass family, Poaceae (Gramineae), subfamily Pooideae in the tribe Stipeae (spear grasses). Nassella comprises at least 116 species (Barkworth et al., 2008; Soreng et al., 2009; Romaschenko et al., 2012). Species currently placed in this genus were originally included in the genus Stipa s.l. and for many years researchers held mixed views regarding the segregation of these genera. However, with strong support from molecular studies, their separation appears to be largely settled, save for a few species (Romaschenko et al., 2012; Cialdella et al., 2014). The name 'Nassella' comes from the Latin noun nassa which means "a fish basket" (Quattrocchi, 2000), probably because these grasses were used for making fishing baskets.

According to Barkworth and Torres (2001), with confirmation from researchers such as Romaschenko et al. (2012) and Soreng et al. (2009), most Nassella species are native to South America, while six are also found in the United States and Canada. The species are mostly native to Argentina, Bolivia, Brazil, Chile, Colombia,

\footnotetext{
* Corresponding author.

E-mail address: amapaura@gmail.com (A. Mapaura).
}

Costa Rica, Ecuador, Guatemala, Mexico, Paraguay, Peru, Uruguay, and Venezuela. The highest species diversity of Nassella occurs in north-western Argentina which is home to 72 species (Barkworth and Torres, 2001).

Eleven Nassella species have been recorded as growing outside their natural ranges (Barkworth and Torres, 2001). Of these, N. neesiana, $N$. tenuissima and $N$. trichotoma have naturalised (sensu Pyšek et al., 2004) and become invasive in Australia, Europe, New Zealand, South Africa and the USA (Howell and Sawyer, 2006; Henderson, 2018; Ranwashe, 2019). The other species which have naturalised outside their natural ranges are not invasive (Barkworth and Torres, 2001). Nassella neesiana, N. tenuissima and N. trichotoma invade disturbed areas, particularly overgrazed pastures, and also indigenous grasslands, including those dominated by Themeda triandra Forrsk in temperate mountains (Faithfull et al., 2012; Taylor et al., 2016). Nassella trichotoma is regarded as a major invader in Australia, New Zealand and South Africa (Wells and De Beer, 1987).

There are no indigenous species of Nassella in South Africa. Three species are known to have naturalised in the country: $N$. neesiana, $N$. tenuissima and N. trichotoma (Fish et al., 2015; Visser et al., 2017; Ranwashe, 2019). All three species are thought to have been 
accidentally introduced to South Africa by the British Army during the Anglo-Boer War (1899-1902), through the ports of East London and Port Elizabeth, possibly as seed in hay from Argentina for horse fodder (Wells, 1978; Henderson, 2018). Only N. trichotoma and N. tenuissima are currently listed as invasive species in category $1 \mathrm{~b}$ of the National Environmental Management: Biodiversity Act (NEM:BA, 10/ 2004): Alien and Invasive Species (AIS) Regulations of 1 October 2014. These regulations stipulate that they cannot be traded or planted in any form and should be removed and destroyed wherever possible.

Research conducted on Nassella in South Africa in the 1970s and 1980s, especially by M.J. Wells, led to widespread awareness and many control campaigns. Effective enforcement of control of Nassella species ended in 2000 when the government subsidy stopped (Henderson, 2018). The termination of these subsidies and the coordinated control efforts also appears to have ended research efforts, the gathering of new information and formal reporting on Nassella invasions.

This paper collates all available information about Nassella invasions in South Africa and identifies research gaps. It specifically seeks to shed light on these questions:

What identification issues exist? What is the current spatial distribution of Nassella? What is the autecology of the genus? What are the social-ecological impacts of Nassella? What control measures are currently applied and what are their strength and limitations? What do we know about Nassella distribution and its response to climate change?

\section{Materials and methods}

The taxonomic delimitations used in this review of Nassella follow Barkworth and Torres (2001), supplemented with insights from Fish et al. (2015). Data were gathered from published and grey literature. Several methods were pursued in order to unearth as much literature as possible. These methods included searching repositories for the three species, following-up on literature cited in references, searching for articles by authors whose works were frequently referenced, and by consulting relevant research institutes in the country. Landowners, practitioners, and rangeland scientists also gave their own perceptions, thoughts and experiences during reconnaissance visits and informal interpersonal and email communications. These were also included, together with the observations and experiences of the authors when no published data could be found. Nassella research in South Africa effectively stopped in the 1980s and no recent scientific research could be found in the literature. However, Australia and New Zealand have similar socio-ecological systems to South Africa (Pyšek et al. 2020), and much research on the invasion ecology of the genus has been undertaken in these countries. This research was extensively consulted for this review, and the implications of this work were cautiously interpreted with reference to the South African context.

Distributional data were gathered from databases such as the Southern African Plant Invaders Atlas (SAPIA) (Henderson and Wilson, 2017), the Global Biodiversity Information Facility (GBIF) (Occdownload Gbif.Org, 2019), Botanical Dataset of Southern Africa (BODATSA) (Ranwashe, 2019) and iNaturalist records marked as Research Grade. These data were used to produce current distribution maps of the three Nassella species (Fig. 1). Unverified records, such as those given by word of mouth were not included. The distributional data were converted to degree decimals and plotted on a map using the Free and Open Source QGIS software.

\section{Description}

Nassella are best distinguished from other members of the tribe Stipeae by the strongly convolute lemma and short, glabrous palea
(Barkworth and Torres, 2001). They are perennial tussock grasses with membranous ligules which are sometimes pubescent or ciliate. The inflorescences are panicles. The Nassella species themselves are similar and difficult to distinguish from each other, particularly outside the flowering season; this is especially problematic for $N$. trichotoma and $N$. tenuissima which have very similar ecologies and growth habits (Jacobs et al., 1998) (Table 1).

\subsection{Similar species in the field}

Nassella highlights the challenges presented by cryptic invaders that are not readily distinguishable from native grasses (Henderson and Wilson, 2017). They are very similar to native Stipa species (Connor et al., 1993; Global Invasive Species Database GISD, 2019) of which South Africa has four indigenous species, including the endemic S. dregeana Steud. var. dregeana (Ranwashe, 2019). As highlighted by Henderson (2018), N. trichotoma looks superficially like Festuca caprina and Tenaxia stricta and has been confused with these species even by experienced researchers. Henderson (2018) also reports that $N$. trichotoma often shares its habitat with $T$. stricta in rocky mountainous areas. The short, white, hairless ligule with a rounded apex found on $N$. trichotoma, differentiates it from T. stricta and similar tussock species which either lack the ligule or possess a ring of hairs around the top of the ligule (Henderson, 2018). As mentioned above, the three Nassella species are also difficult to distinguish from one another. This difficulty in species identification explains why no records are submitted through citizen science such as SAPIA (Henderson and Wilson, 2017). On 8 September 2020 there are 7 observations of Nassella species: 3 (2) for $N$. neesiana, 2 for $N$. pulchra and 2 (1) for $N$. trichotoma (numbers of "Research Grade" observations are in brackets). Nassella pulchra has not naturalized and is not known to be invasive.

\section{Distribution and ecology}

Nassella species are $C_{3}$ grasses, and are therefore generally restricted to temperate regions of the world where they inhabit a wide ecological range (Milton, 2004; Romaschenko et al., 2008). The species occur mainly in degraded pastures but also in natural grasslands and open woodlands (Henderson, 2001; Taylor et al., 2016). Temperature tolerance ranges from as low as $-5{ }^{\circ} \mathrm{C}$ to about $25^{\circ} \mathrm{C}$ and they can survive short periods of frost and ice cover (Healy, 1945; Bourdôt et al. 2012). They favour areas with annual rainfall between 300 and 800 mm (Healy, 1945; Wells and De Beer, 1987; Henderson, 2001). They are therefore better at tolerating droughts than most pasture species in areas where they occur (Wells, 1977; Miller, 1998; Grech et al., 2012). Nassella species have been shown to grow in a variety of soil types and fertility ranging from poor welldrained acidic soils (Campbell, 1998) to fertile soils (Wells and De Beer, 1987; Badgery et al., 2005). The distribution of the species is influenced by soil disturbance and reduction in native perennial grasses (Healy, 1945; Badgery et al., 2005).

In South Africa Nassella is restricted to the montane grasslands of the Eastern and Western Cape mountains (Fig. 1).

Nassella neesiana is native to Argentina, Bolivia, Brazil, Chile, Ecuador, Paraguay, Peru, and Uruguay (Barkworth and Torres, 2001; Soreng et al., 2009). It has naturalised in Australia, Europe, New Zealand, and South Africa (Barkworth and Torres, 2001; Fish et al., 2015; Henderson, 2018; Howell and Sawyer, 2006; Verloove, 2005). While it is considered a serious invader in Australia and New Zealand (Howell and Sawyer, 2006; Henderson, 2018; Ranwashe, 2019), it is not currently listed in the NEM:BA regulation although it could be a threat in South Africa judging from the distribution pattern shown on Fig 1. It is known to have naturalised in the Eastern Cape, Western Cape and the Free State provinces (Fig. 1) at altitudes between $600 \mathrm{~m}$ and $1700 \mathrm{~m}$ (Germishuizen and Meyer, 2003). 


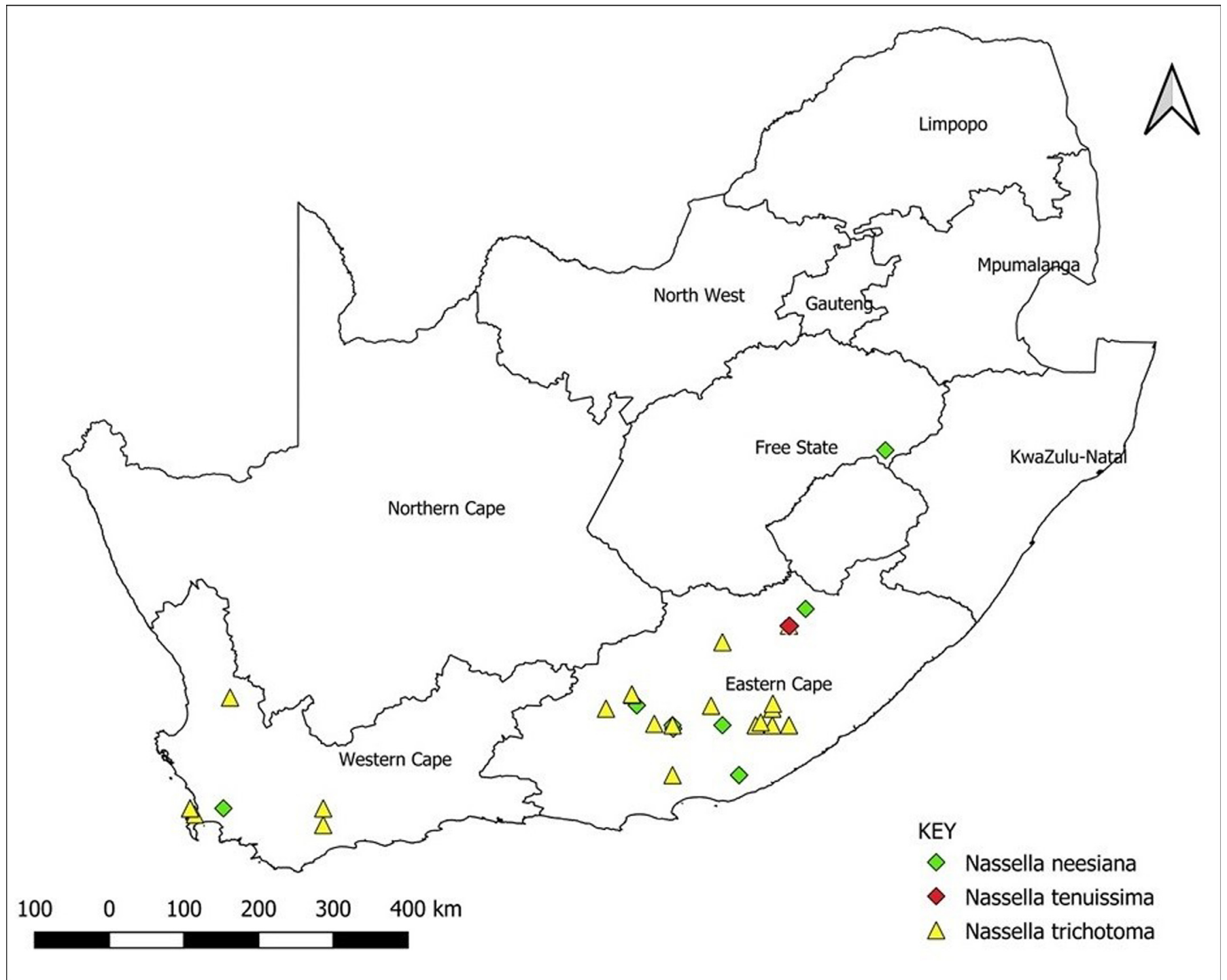

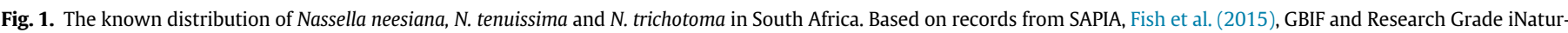
alist observations.

Table 1

Description of the defining features of three naturalised Nassella species in South Africa (Barkworth and Torres, 2001; Fish et al., 2015).

\begin{tabular}{|c|c|c|c|}
\hline Character & Nassella neesiana & Nassella tenuissima & Nassella trichotoma \\
\hline Synonyms & Stipa neesiana Trin. and Rupr & Stipa tenuissima Trin. & Stipa trichotoma Nees \\
\hline Common names & Chilean needle grass & Mexican feather grass, white tussock, witpolgras & $\begin{array}{l}\text { Nassella tussock; serrated tussock, Nassella- } \\
\text { polgras }\end{array}$ \\
\hline General & $\begin{array}{l}\text { A perennial tussock forming } \\
\text { grass, up to } 1 \mathrm{~m} \text { high. }\end{array}$ & $\begin{array}{l}\text { A perennial tussock forming grass, up to } 1 \mathrm{~m} \\
\text { high. } \\
\text { Tussock distinctly white in winter. Culms slen- } \\
\text { der and wiry. }\end{array}$ & $\begin{array}{l}\text { A perennial tussock forming grass, up to } 0.65 \mathrm{~m} \\
\text { high. } \\
\text { Mature tussocks droop }\end{array}$ \\
\hline Leaves & $\begin{array}{l}\text { Flat, } 300 \mathrm{~mm} \text { long and } 1-5 \mathrm{~mm} \\
\text { wide, strongly ribbed on adax- } \\
\text { ial surface with rough margins }\end{array}$ & $\begin{array}{l}\text { Very tightly rolled inward, and up to } 700 \mathrm{~mm} \\
\text { long and } 0.5 \mathrm{~mm} \text { wide, appear as thin wiry fila- } \\
\text { ments which are rough to touch. }\end{array}$ & $\begin{array}{l}\text { Tightly rolled, } 80-500 \mathrm{~mm} \text { long and } 0.5 \mathrm{~mm} \\
\text { wide, hairless with very fine serrations. Rough } \\
\text { when stroked downwards. }\end{array}$ \\
\hline Ligules & Truncate with a few hairs & Acute & Obtuse \\
\hline Inflorescence & Open panicle & $\begin{array}{l}\text { Slender, compact panicle rarely extending above } \\
\text { leaves. }\end{array}$ & $\begin{array}{l}\text { Open, much-branched panicle, detaching at } \\
\text { maturity, leaving the plants free of inflorescen- } \\
\text { ces for most of the year. }\end{array}$ \\
\hline Spikelet & 15-17 mm long (excluding awn) & 4-5 mm long (excluding awn) & $6-8.5 \mathrm{~mm}$ long (excluding awn) \\
\hline Glume & Longer than lemma & & \\
\hline Lemma & & Elliptic & Obovate \\
\hline Awns & $50-120 \mathrm{~mm}$ long, geniculate & $\begin{array}{l}\text { 45-90 mm long, unnoticeably geniculate, cen- } \\
\text { trally placed on lemma }\end{array}$ & $15-35 \mathrm{~mm}$ long, off centre of lemma \\
\hline Time of flowering & November to March & January & August to March \\
\hline
\end{tabular}


Nassella tenuissima is native to Argentina, Chile, Mexico, and USA (Barkworth and Torres, 2001; Jacobs et al., 1998; Soreng et al., 2009). It has become naturalised in New Zealand, Australia, Europe, South Africa and the USA (outside the natural range) (Barkworth and Torres, 2001). Nassella tenuissima has been widely distributed mostly as a result of its value as a horticultural grass. In South Africa, the species has so far only been recorded from a single locality in the Eastern Cape Drakensberg Mountains (Fig. 1) (Henderson, 2001; Fish et al., 2015; Ranwashe, 2019). A search in February 2020, by a team of grass taxonomists and one of the authors could not locate the species. While in other parts of the world it has been recorded at altitudes ranging from near sea level to $2900 \mathrm{~m}$ (Jacobs et al., 1998; Occdownload Gbif.Org, 2019), the recorded populations in South Africa occur at altitudes between 2000 and $2600 \mathrm{~m}$ (Germishuizen and Meyer, 2003) and only in grassland (Henderson, 2007).

Nassella trichotoma is native to Argentina, Bolivia, Brazil, Chile, Peru and Uruguay (Wells, 1977; Westbrooks and Cross, 1993; McLaren et al., 1998; Barkworth and Torres, 2001). It is invasive in Australia, New Zealand and South Africa (McLaren et al., 2004; Howell and Sawyer, 2006; Henderson, 2018; Ranwashe, 2019), with some invasive populations in parts of Europe (Campbell, 1982; Barkworth and Torres, 2001). In South Africa, it has been recorded as being invasive in the Western, Eastern and Northern Cape provinces (Fig. 1), and there are unconfirmed records from Limpopo, Gauteng, Free State and Mpumalanga (Ranwashe, 2019). By 1985 it had invaded about 70000 ha with just over 9000 ha of this being moderately to heavily invaded (Wells and De Beer, 1987). Wells and De Beer (1987) projected that by the mid-2020s about 2 million ha of South Africa could be invaded. The possibility of this projection coming true is unknown as data on the extent of invasion are not available. It has been recorded at altitudes between 100 and $1600 \mathrm{~m}$ (Germishuizen and Meyer, 2003). It is commonly encountered in savanna and grassland but also occurs in fynbos, Nama-karoo and succulent karoo vegetation types (Henderson, 2007).

\section{Reproduction, dispersal and germination}

\subsection{Reproduction}

Nassella species appear to rely exclusively on sexual reproduction via seeds (Campbell, 1982) which are produced in large quantities. For example, $N$. trichotoma has been shown to produce as many as 100000 seeds per plant per year (Wells, 1977; Wells, 1978; Campbell, 1982; Wells and De Beer, 1987), giving an estimated production of 900-3400 million seeds per hectare in heavily invaded areas (Healy, 1945).

Nassella neesiana and $N$. tenuissima produce chasmogenes ("normal seeds') and cleistogenes (seeds produced in closed stem flowers), and can also self-pollinate (Connor et al., 1993; Jacobs et al., 1998; Faithfull et al., 2012). The cleistogenes are reportedly more common when the production of chasmogenes is suppressed, such as during prolonged mowing and overgrazing (Kriticos et al., 2010). Cleistogamy ensures that the species persist and keeps the seed bank replenished during those periods when the production of inflorescences is subdued.

\subsection{Dispersal}

Seeds can be dispersed over long distances, especially in the case of $N$. trichotoma whose seeds are borne on inflorescences that detach readily when seeds mature and can be blown for great distances, as much as $16-30 \mathrm{~km}$ per day depending on wind speed and physical impediments (Wells, 1978; Campbell, 1982; Joubert, 1984). However, $N$. neesiana and $N$. tenuissima are usually only dispersed for short distances because their seeds remain attached to the plant. This could explain why $N$. tenuissima seems not to have spread from the single locality from where it has been reported in the Eastern Cape.

Seeds are also dispersed by many other agents such as agricultural machinery, floodwaters, in mud or soil, clothing, trains, and cars (Wells, 1978; Campbell, 1982; Cooperative Research Centres, 2003). Seeds can pass through the digestive system of cattle (Healy, 1945) and sheep (Cook, 1998) unharmed and thus can be spread in animal faeces. However, the consumption of Nassella by livestock is limited and mostly occurs by accident during the process of grazing more palatable forage (Bläßet et al., 2010). Seeds can also be spread through silage and hay if proper care is not taken. This is particularly important in cases where fodder has to be moved large distances to feed livestock due to a lack of available forage. (Weller et al., 2016, Weller et al., 2016).

\subsection{Germination and growth}

Most of the seed bank for Nassella species is found in the top $2.5 \mathrm{~cm}$ of the soil; seeds close to the soil surface lose viability more rapidly than seeds buried deeper, and deep-buried seeds experience stronger dormancy (Bourdôt and Hurrell, 1992; Faithfull, 2012; Joubert, 1984). Once in the soil the seeds of $N$. trichotoma can lie dormant for up to 20 years (Wells, 1977; Wells, 1978; Wells and De Beer, 1987). However, the viability of seeds declines quickly. Taylor (1987) found that after 6 months viability declined to between 20 and $61 \%$ under field conditions in New Zealand. This is not the case with all Nassella species; for example $N$. neesiana seeds lose viability at a rate of $38 \%$ per annum (Connor et al., 1993) and so may not last for more than a few years in the soil (Bourdôt and Hurrell, 1992). The soil seed bank can be immense, ranging from 1700 to more than 42000 seeds $/ \mathrm{m}^{2}$ in New Zealand (Healy, 1945) and up to 75000 seeds/ $\mathrm{m}^{2}$ for $N$. trichotoma in South Africa (Joubert, 1984) although they are normally found in much lower quantities with a high proportion showing damage from factors such as animal trampling and insect predation and hence probably not viable (Joubert, 1984). While $N$. trichotoma seeds are dispersed everywhere, seedlings do not take hold in healthy native grasslands, possibly due to shading (Campbell, 1982; Joubert, 1984; Faithfull, 2012). Germination or survival of seedlings is probably prevented by shading, with evidence of higher germination under unshaded conditions in undamaged seed (Taylor, 1987). Most seeds that germinate do not survive the first summer due to competition for moisture with established plants (Badgery, et al. 2008). These two mechanisms work together to ensure that $N$. trichotoma does not establish easily in dense native grasslands. Some stakeholders in the Eastern Cape have pointed out that N. trichotoma invasions in South Africa start from a point of initial establishment and expand outwards from that point as new plants establishing themselves close to already established plants (Fig. 2). This suggests that most of the seeds fall close to parent plants even though they have the potential to be dispersed further.

Seeds can germinate at any time of the year, but mostly in autumn and winter in South Africa (Joubert, 1984). Germination appears to be regulated by rainfall and temperature, with low temperatures and droughts limiting germination (Bourdôt and Hurrell, 1992). Seeds germinate over a wide range of conditions and over a long period (Healy, 1945), probably as a result of dormancy mediated by the permeability of testa (Campbell, 1998). The need for dormancy is demonstrated by the fact that fresh seeds show lower germination rates compared to seeds set in the previous years (Lamoureaux and Bourdôt, 2002; Lamoureaux et al., 2006). Removing the testa and cutting off the awn-end of seed increases germination rate in the seeds (Campbell, 1998).

Nassella trichotoma grows more slowly than desirable pasture grasses and also flowers several years after germination (Campbell, 1998). Research in New Zealand has shown that tussock expansion is much faster than previously believed but is rarely noticed until flowering starts (Bourdôt and Saville, 2019). The seeds of $N$. 


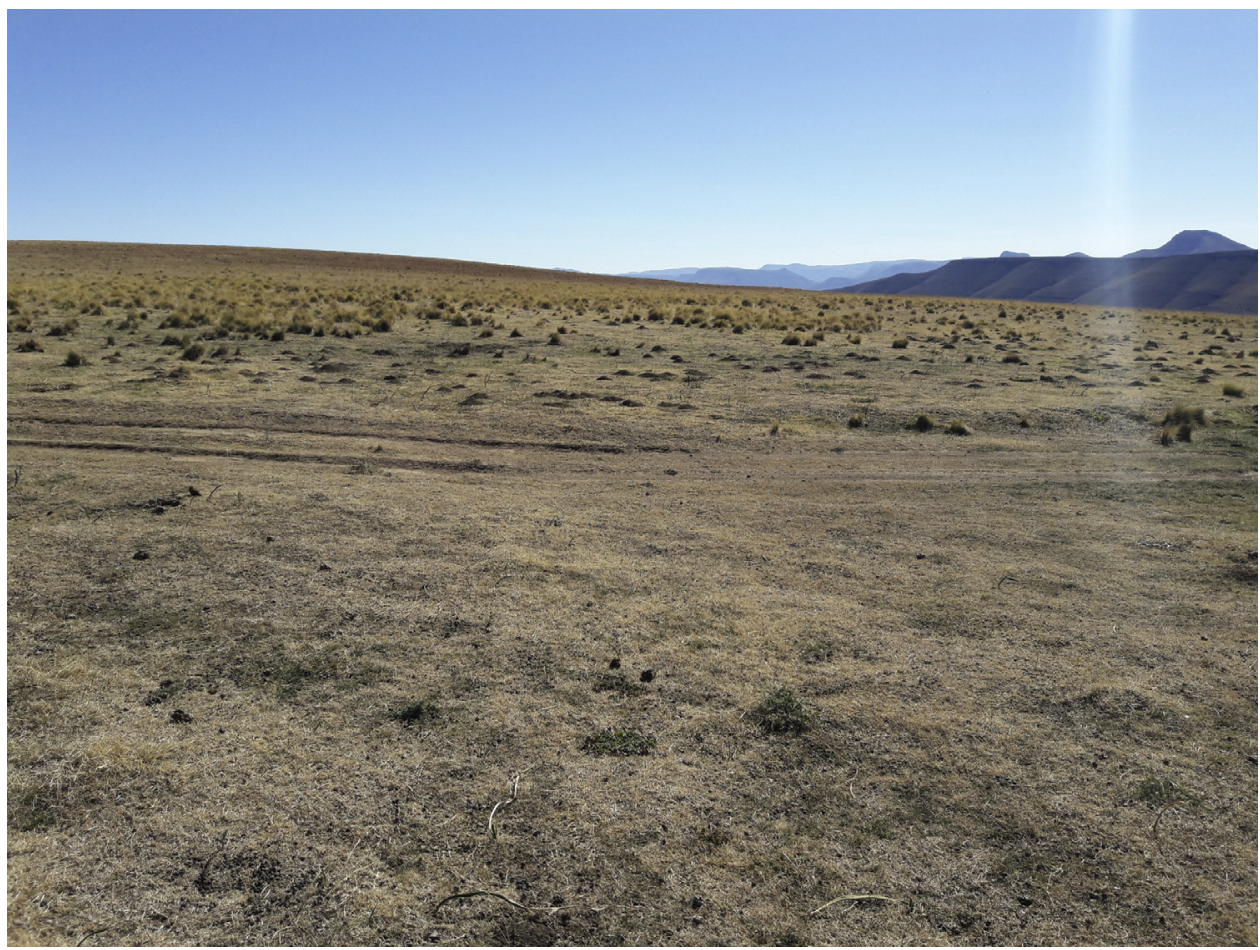

Fig. 2. A Nassella trichotoma patch (tufted grasses in background) expanding in an overgrazed paddock in the Boschberg near Somerset East, Eastern Cape, South Africa.

trichotoma are viable well before the panicles extend above the tussock canopy (Lamoureaux and Bourdôt, 2002; Lamoureaux et al., 2006). It produces a very strong rooting system, reaching depths of $20 \mathrm{~cm}$, which makes uprooting difficult even for young plants (Wells, 1977; Wells and De Beer, 1987).

Nassella neesiana, on the other hand, grows so rapidly that it is often difficult to distinguish the seedling and juvenile stages (Faithfull, 2012). Seeds can germinate and plants mature and produce viable seeds within a single year (Bourdôt and Hurrell, 1992; Faithfull, 2012). On poor soils, however, flowering may be delayed until the third or fourth year due to poor vegetative growth (Campbell, 1998). The fast growth rate ensures that the plants outcompete all other grasses and occupy open spaces rapidly. Moretto and Distel (1998), reported that $N$. tenuissima is a poor root and shoot competitor, and so establishes and thrives in vegetation gaps where there is no competition from other grasses, and where seed dormancy is broken by fluctuating temperatures. They also noted that germination was concentrated during the rainy season since the seeds are highly susceptible to desiccation.

\section{Uses}

Since their accidental introduction into South Africa, Nassella species have not been used for anything. Several uses have, however, been noted around the globe, especially in the native range of the taxa. All species are occasionally grazed by goats and cattle when they are still young and in the active vegetative growth stage (Campbell, 1982; Westbrooks and Cross, 1993). Nassella tenuissima is also used as an ornamental grass in some countries, but this use is illegal in many countries due to the possibility of it escaping and becoming invasive. In Argentina, N. tenuissima is reportedly used for thatching (Global Invasive Species Database GISD, 2019).

\section{Impact}

Research to date suggests that invasive alien grasses generally have a greater socio-economic impact than environmental impact in
South Africa (Visser et al., 2017; Nkuna et al., 2018). However, since the majority of recorded impacts are on crop and animal production there is a bias towards socio-economic data (Nkuna et al., 2018). The abundance of Nassella plants can increase rapidly, leading to them assuming dominance over whole pastures, completely displacing both planted and natural grass species (Fig. 3) (Faithfull 2012). Of the three Nassella species, $N$. trichotoma is the most devastating and widespread in South Africa, and known to completely smother even planted pastures (Wells, 1977). Its feat as an invader led Wells (1977) to conclude that: '. . this is almost the perfect weed, a beautifully adapted, highly efficient organism: a self-perpetuating factory of valueless fibres.'

\subsection{Environmental impact}

There is a general lack of data on the environmental impacts of Nassella species, especially in South Africa (Visser et al., 2017). In general, Nassella invasions are associated with reduced invertebrate diversity, altered fire regimes, and the suppression of co-occurring native grasses (Faithfull, 2012). Nassella neesiana, and possibly all Nassella species, has an increasing impact on native grass diversity as its residence time increases (Faithfull, 2012). It has also been reported that even though numerous native generalist insect species consume it in Australia (Faithfull, 2012), it significantly reduced invertebrate abundance, composition, and richness compared to native-grass dominated areas (Faithfull, 2012). However, much of the loss of diversity in invaded areas probably precedes invasion caused by anthropogenic disturbances such as mowing, major soil disturbance, and previous control with herbicides (like flupropanate or glyphosate) that also kill many of the native species (Faithfull, 2012).

Invasion of $N$. trichotoma has been reported to be associated with altered fire regimes, for example in the Geelong region of Victoria, Australia, invaded stands resulted in extending the fire season by as much as two months (McLaren et al., 2004). The altered fire regime has major impacts on the regeneration of native species through changing the soil carbon and nitrogen status and soil microbial structure and function (Dickens and Allen, 2014). 


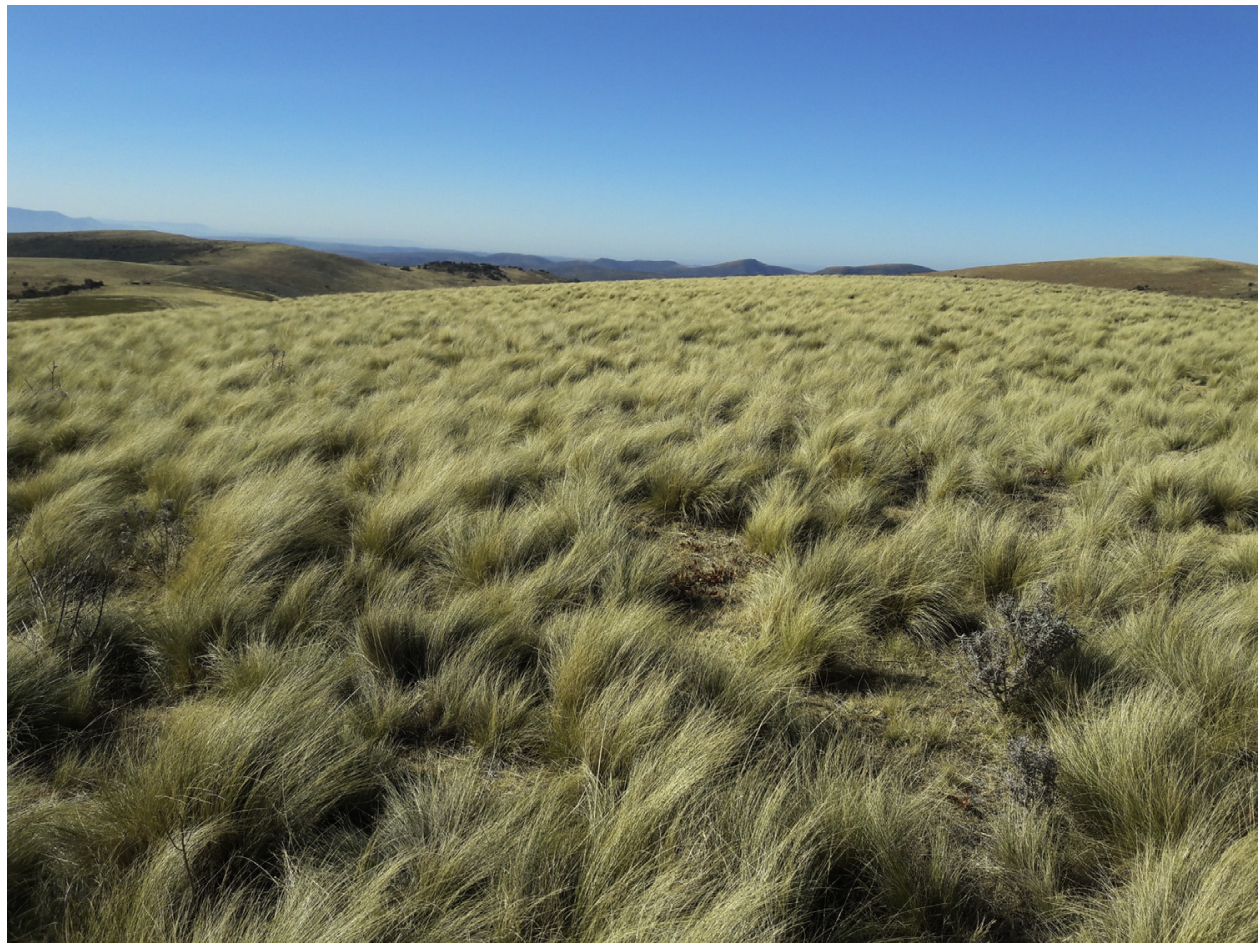

Fig. 3. A paddock invaded by Nassella trichotoma on the Boschberg near Somerset East, Eastern Cape Province, South Africa (Photo A. Mapaura).

Soil seed banks in areas invaded by Nassella species include seeds of other species, both native and non-native, but many of these species are not represented in the above-ground plant assemblage (Joubert, 1984; Wells and De Beer, 1987; Faithfull, 2012). Joubert (1984) suggested that this could be due to allelopathic interactions, but no research has been done to confirm this type of interaction. However, it is not clear that all invasive populations of Nassella have such an effect; for example, $N$. trichotoma in natural montane grasslands in the Eastern Cape co-occurs with several species of native grasses (A. Mapaura, pers. obs.). The non-germination of indigenous grasses in densely invaded patches of Nassella could also be a result of the dense cover of Nassella which prevents light from reaching the soil to stimulate seed germination, and also competition for other resources, particularly water. The effect of canopy cover is more likely considering that after clearing the Nassella plants seeds of other native plant species are able to germinate and establish (Joubert, 1984). The mechanisms whereby Nassella impacts native species are not understood, although much research is currently underway, especially in Australia and New Zealand. Research is needed to determine the factors leading to the suppression of native grasses in Nassella-invaded patches.

\subsection{Socio-economic impact}

In pastures the more palatable grasses and plants are generally smothered by less palatable and poisonous species as the former are preferentially eaten by animals (Wells et al., 1983). This progressively reduces the quality of the pastures, impacting negatively on the pastures' carrying capacities (Viljoen, 1999; Richardson et al., 2011; Nkuna et al., 2018). As palatable pasture plants decrease, inedible and indigestible plants such as Nassella species increase, reducing native grass and forb richness by as much as 50\% (Morgan, 2001; Faithfull, 2012). Nassella species have been reported to impact native species more than other non-native species present in an area where they invade (Faithfull, 2012).

Nassella species are not palatable and hence increase as the palatable grasses decrease in pastures, especially where there is bad pasture management (Wells, 1977; Wells and De Beer, 1987). Nassella trichotoma has a very high fibre content (as high as $86 \%$ ) and very low nutritive value (protein content as low as $4 \%$ ), making it non-nutritional hence seldom grazed by animals (Wells and De Beer, 1987). Furthermore, if animals are forced to graze it, the fibres, which are indigestible, can form boles in the rumen, causing rapid loss of health, which may lead to death (Wells and De Beer, 1987; Campbell, 1998). This reduction in pasture quality can be massive, leading to sub-economic carrying capacities (Campbell, 1998; McLaren et al., 2004; Anderson et al., 2010). In New Zealand, carrying capacity reductions of up to $90 \%$ were reported on some farms, leading to the abandonment of sheep farming (Healy, 1945). In worst case scenarios in New South Wales, Australia, some farms were so heavily invaded that the cost of control was higher than the value of the farm, leading farmers to abandon farming or to sell their farms and seek alternative employment (Campbell, 1998). Some farmers in the Eastern Cape, South Africa, have lost the use of part of their farms to Nassella invasion (A. Mapaura pers. obs.).

In monetary terms, losses can be huge. Productivity losses and management costs were estimated to range from as little as \$ AUD7.00 ha $\mathrm{ha}^{-1}$ for light-invaded areas controlled by hand to $\$$ AUD122.00 ha ${ }^{-1}$ for heavy invasions in SE Australia in the early 1980s (Vere and Campbell, 1984). Most of the losses were suffered by the wool and lamb industries due to reduced carrying capacity on invaded farms (Vere and Campbell, 1984). Young animals, especially lambs, can have their skin or eyes damaged by the sharp awns, while the awns are difficult to remove from wool and reduce its quality (Anderson et al., 2010; Campbell, 1998).

\section{Management}

\subsection{General}

South Africa seems to be less susceptible to invasion by nonnative grasses than many other parts of the world (Visser et al., 2016). Nonetheless, invasions of several species of non-native grasses are having major, and rapidly growing, impacts on human livelihoods 
and biodiversity. Several researchers have made urgent calls for more effective management of invasive grasses, including Nassella, in South Africa (Wells et al., 1983; Milton, 2004; Henderson and Wilson, 2017; Visser et al., 2017; Henderson, 2018; Nkuna et al., 2018). The spread of invasive alien species is facilitated by the increasing global movement of people and goods, while anthropogenic environmental changes facilitate their establishment and proliferation (Early et al., 2016). In light of limited resources and a multiplicity of competing needs, it is important to evaluate both monetary and non-monetary benefits of all available control methods before embarking on any action, or deciding to take no action (Bourdôt et al., 2015; Hanley and Roberts, 2019).

The ability to control any invasive species depends on the ability of managers to identify it correctly at every stage of its growth and their ability to notice it before it has become a problem (Wells, 1977; Wang et al., 2016). However, as discussed above, Nassella species are cryptic; their presence is often noticed after the species are well established and are causing dramatic impacts (Wells, 1977; McLaren et al., 2004; Smith and Lamoureaux, 2006). Late flowering in $N$. trichotoma, for example, makes early detection difficult since the species is easily distinguishable when in flower, meaning that by the time they are detected they will be already established and difficult to control (Campbell, 1998; Smith and Lamoureaux, 2006).

Following the pioneering work of M.J. Wells and others in the 1970 s and 1980s, N. trichotoma and N. tenuissima, were listed as invasive species in South Africa, and were placed in category 1b in the NEM:BA regulations. Vigorous awareness and control campaigns were launched by the Department of Agriculture in the 1980s and 1990s. The Government provided landowners with task teams and subsidised herbicides (Henderson, 2018). However, all progress made with tackling these invasions was lost when the subsidy was removed, and the herbicide flupropanate was withdrawn from sale in 1997; government-driven control and control enforcement thus effectively stopped. Since then there has been no centrally coordinated effort to control Nassella invasions in South Africa, and farmers have borne the burden of addressing these invasions alone, often leading to individual farmers working independently of their neighbours (Henderson, 2018), or not at all. The ideal control measure will be one that reduces the soil seed bank, while at the same time minimising re-invasion from neighbouring areas (Joubert, 1984; Bourdôt and Hurrell, 1992). To prevent re-invasion, an area-wide control system is crucial, to ensure that neighbouring property owners and managers cooperate to deal with the invasion (Miller, 1998).

\subsection{Cultural control}

Nassella grasses are unpalatable - most animals will not ordinarily graze them (Wells and De Beer, 1987; Anderson et al., 2006); this greatly reduces the potential for using livestock to control Nassella invasions (Grech et al., 2012). Goats have, however, been reported to graze actively growing low Nassella weed population densities of less than $20 \%$ ground cover but due to low nutritive value grazing is avoided unless there are no other options (Campbell, 1982; Westbrooks and Cross, 1993). Nassella neesiana reportedly produce good feed in the early vegetative stage and so livestock can be used to reduce their productivity (Westbrooks and Cross, 1993; Miller, 1998; Cooperative Research Centres, 2003). However, N. neesiana has a very short juvenile stage which means that it is available for grazing for a very brief period (Faithfull, 2012). To reduce the potential of spreading the seeds through silage, the silage can be quarantined for at least 6 weeks to ensure that the seeds are not viable and also to diminish the sharpness of the seeds which can be injurious to the intestinal lining of animals (Weller et al., 2016).

Afforestation has been used in Australia and New Zealand to control Nassella especially in cases where agriculture was no longer possible due to heavy invasions (Healy, 1945; Campbell, 1982;
Miller, 1998; Jones et al., 2000). However, it takes up to six years to shade-out the weed and prevent flowering, and another four years before the tussocks die (Wells, 1977; Campbell, 1982; Miller, 1998). It would take many more years for the seedbank to be depleted. To speed up the establishment of tree seedlings, flupropanate can be sprayed to kill Nassella without affecting the tree seedlings (McLaren et al., 2008). As noted, before, Nassella species invade grassland ecosystems, and afforestation is not always possible, practical nor desirable in these ecosystems. Tree species that could potentially be used for such purposes are mainly non-native species that themselves cause major problems as invasive species (Richardson et al., 2020). All these reasons make afforestation an unsuitable control option for South Africa.

Native species may lack or have transient seed banks which limits their recruitment and reestablishment, hence are not efficient at naturally colonising open spaces (Morgan, 2001). Experiments in Australia concluded that native grasses have low survival rate and natural densities making them poor competitors against Nassella species. (Morgan, 2001). Seeding of pastures with native grass species after Nassella removal has, therefore, been suggested as a possible solution to cover the bare ground left after Nassella removal (Miller, 1998; Cooperative Research Centres, 2003). However, seedlings have little to no effect in smothering Nassella since most of the native grasses grow much slower than Nassella (Faithfull, 2012; Grech et al., 2012). Unlike most $C_{3}$ grasses, Nassella species. are more drought hardy and tolerate poor soils better than most good pasture grasses, hence for an effective seeding method to work a grass with similar or better traits has to be found to suppress Nassella both in the short and long term (Miller, 1998; Grech et al., 2012).

Burning the dead organic material on the soil surface may destroy between $18 \%$ to $20 \%$ of the Nassella seeds present in the top soil (Joubert, 1984; Faithfull, 2012), suggesting that this treatment may be used to reduce the seed bank, bearing in mind that fire also stimulates seed germination. However, although Nassella grasses burn readily, they also recover quickly especially if the tuft is not burnt completely, while associated native species are often killed (Healy, 1945). Fire also reduces the seed bank of good pasture species in the soil leaving the ground bare and creating ideal conditions for reinvasion by Nassella species (Campbell, 1982; Joubert, 1984; Wells and De Beer, 1987). Burning as a control measure may, therefore, inadvertently increase rather than decrease Nassella populations. More research is required to ascertain how different regimes of burning affect Nassella invasion dynamics (Badgery, 2004). Nassella often invades fire adapted natural grassland ecosystems dominated by T. triandra, in both Australia and South Africa (Faithfull, 2012; Faithfull et al., 2012) which makes fire exclusion as a control method unviable. The hot fires that would eventually result after years of fire exclusion, are often not a problem for Nassella, which always has some seeds left unburnt due to high seed bank, and seeds can be reintroduced by wind from distant areas and take advantage of the reduced cover (Healy, 1945; Badgery, 2004; Faithfull, 2012).

\subsection{Mechanical control}

Small, low-density patches and isolated plants can be controlled by hand weeding or digging when equipment is cleaned meticulously and the clippings are destroyed (Healy, 1945; Wells, 1977; Cooperative Research Centres, 2003; Taylor et al., 2016). However, the potential exists for exacerbating the invasions (Faithfull 2012; Taylor et al., 2016). These methods are of little use in natural grasslands where native grasses such as $T$. triandra have vulnerable growing points and lack the ability to grow horizontal tillers compared to Nassella (Faithfull et al., 2012). Grubbing as a management tools cannot eradicate Nassella but can reduce densities or keep population levels static (Bourdôt et al., 1992; Smith and Lamoureaux, 2006). Grubbing was also found to be more effective against medium sized 
tufts as opposed to large and small plants but more research is required to determine the best time to perform it based on Nassella population dynamics (Smith and Lamoureaux, 2006; Bourdôt and Saville, 2019).

Cultivating or ploughing has been suggested as a possible control mechanism for managing Nassella invasions (Wells, 1977). Nassella seeds are concentrated in the top $2.5 \mathrm{~cm}$ of the soil (Joubert, 1984; Bourdôt and Hurrell, 1992; Faithfull, 2012), so ploughing has the potential to bury them to depths they cannot emerge from (Campbell, 1982), but this has to be done with care since the seeds can attain a state of permanent dormancy (Bourdôt and Hurrell, 1992). However, ploughing may inadvertently exacerbate the problem by bringing deep-buried seeds to the surface where they can germinate (Wells, 1977; Westbrooks and Cross, 1993). For this method to be successful, ploughing must be done when the soil is dry and must be repeated every year for many consecutive years until the soil seed bank has been exhausted (Wells, 1977; Bourdôt and Hurrell, 1992). In Australia, cultivation has been used successfully in areas where the land is arable and soil fertility is reasonable. Foraging crops are planted for 2-3 years to reduce the soil seedbank, followed by sowing of competitive pasture species (Campbell, 1998). However, Nassella is often found in areas which are rocky and difficult to access, making ploughing futile (Grech et al., 2012). In natural rangelands, such as those being invaded by Nassella in South Africa, ploughing is undesirable as it would have major impacts on forb diversity (which is the richest component of grassland flora).

\subsection{Chemical control}

Several herbicides have been used to manage Nassella invasions in different parts of the world. Most of the herbicides are based on formulations that include glyphosate or flupropanate as active ingredients (Viljoen, 1987; Wells and De Beer, 1987; Grech et al., 2012). Flupropanate has been championed as the panacea for Nassella invasions for many years because it was shown to have over $90 \%$ efficiency in killing Nassella over a wide range of environmental conditions (Wells, 1977; Viljoen, 1987; Campbell, 1998; Viljoen, 1999; Conolly and Taylor, 2016). Although it can take more than a year to kill the plants completely, it is easy to use, is non-toxic to mammals and was once considered highly selective, especially when applied to young Nassella plants (Viljoen, 1987; Wells and De Beer, 1987; Campbell and Ridings, 1988). However, recent research shows that it is not as specific as previously thought as it impacts many native species (Campbell and Van de Ven 1996; Grech et al., 2014; Lusk et al., 2017). Glyphosate has also been used extensively and has been shown to be effective against seed-head production (Campbell, 1998), but it is a broad spectrum herbicide that is indiscriminate in its impacts on non-target species (Grech et al., 2012). While glyphosate and flupropanate are effective independently, their effectiveness will be reduced if they are mixed Taskforceherbicide, 2020).

Viljoen (1987) found that flupropanate was effective at lower rates than recommended with less effect on non-target species, which also greatly reduced costs (Viljoen, 1987; Wells and De Beer, 1987; Campbell and Ridings, 1988; Campbell, 1998). Other researchers also reported that once applied, the chemical has a long residual action that prevents germination and establishment of seedlings for 3-5 years, (Viljoen, 1987; Campbell, 1998; Viljoen, 1999). However, recent studies seem to suggest that these results may not always hold true. For example, flupropanate has been shown to negatively impact beneficial pasture grasses and forbs even at the recommended dosage (Grech et al., 2014; Lusk et al., 2017). Furthermore, research in New Zealand showed that the residual effect was shorter than widely believed (Bourdôt et al., 2017).

Application of flupropanate was found to increase both bare ground and broad leaf weeds especially in grazed areas (Wells and
De Beer, 1987; Grech et al., 2014; Lusk et al., 2017). This can lead to reinvasion by Nassella once the residual effect has diminished (Badgery et al., 2008; Lusk et al., 2017) and so follow-up spraying is required (Grech et al., 2012). However, follow-up spraying would have to be done over many years to deplete the seedbank, making respraying uneconomical (Viljoen, 1987). The increase in bare ground, (Fig. 4), and in broadleaved species reduces pasture palatability and quality (Grech et al., 2014); this could be addressed by seeding treated areas with productive pasture species.

An increasing number of $N$. trichotoma populations are reportedly becoming resistant to flupropanate in Australia due to continuous use of the herbicide over long periods (McLaren and Anderson, 2011; ; Powells, 2018). Flupropanate resistance in South Africa has not yet been investigated.

\subsection{Biological control}

There has been a perception that the uniform and simplistic architecture of grasses and lack of or limited secondary metabolites in grasses makes polyphagy common, limiting the use of classical biological control (hereafter referred to as biocontrol) for grasses in general (Evans, 1991). A further deterrent has been the concern over potential non-target damage on important grass crops (Briese et al., 2000). However, a recent study by Sutton et al. (2019) has demonstrated that many grasses have suitably specific and damaging herbivores to warrant consideration for biocontrol.

A biocontrol programme was initiated on Nassella in South Africa and the first surveys for herbivores were done by Wells (1977) in the native range in Argentina looking for potential biocontrol agents to be released on $N$. trichotoma. This survey determined high levels of herbivory, and a follow up survey by Erb (1988) identified ten species of weevil (Coleoptera) and two moth species (Lepidoptera). However, none of these herbivores were found to be suitably host-specific and this programme was discontinued.

Since then, research into biocontrol on Nassella, specifically $N$. neesiana and $N$. trichotoma, has been undertaken in Australia and New Zealand. Surveys in the native range in Argentina since 1995 have found an additional 22 potential agents (Table 2). To date, only one of these agents, a fungus (Uromyces pencanus), has been approved for release after completion of host-specificity testing and is due for release in New Zealand pending export permits (Anderson et al. 2017). Many of the potential agents on Nassella have been found to be host-specific to each species and therefore each Nassella species will likely require its own biocontrol agent.

\subsection{Integrated control}

Integrated control of invasive plants involves a combination of at least two primary control methods viz. cultural, mechanical, chemical, and biological. For many weed species, the best control is achieved when a combination of control measures is used (Cooperative Research Centres, 2003).

Wells (1978), working in South Africa, detailed an integrated strategy based on prevention of seeding by removing and burning seed heads, killing mature tussocks by chipping, ploughing or spotspraying and prevention of seed dispersal by planting windbreaks, keeping stock away at seeding time, maintaining a good plant cover, particularly on the veld, by not burning. This strategy is essentially the same as that advocated for Australia (Campbell, 1998; Miller, 1998), where it has been concluded that a plan to limit seed reinvasion must be in place to support other control measures, such as using appropriate growing regimes, fertilisers and spot-spraying. Underpinning this integrated control tactic is the realisation that a competitive environment needs to be maintained to prevent (re) invasion (Wells, 1978; Campbell, 1998). 


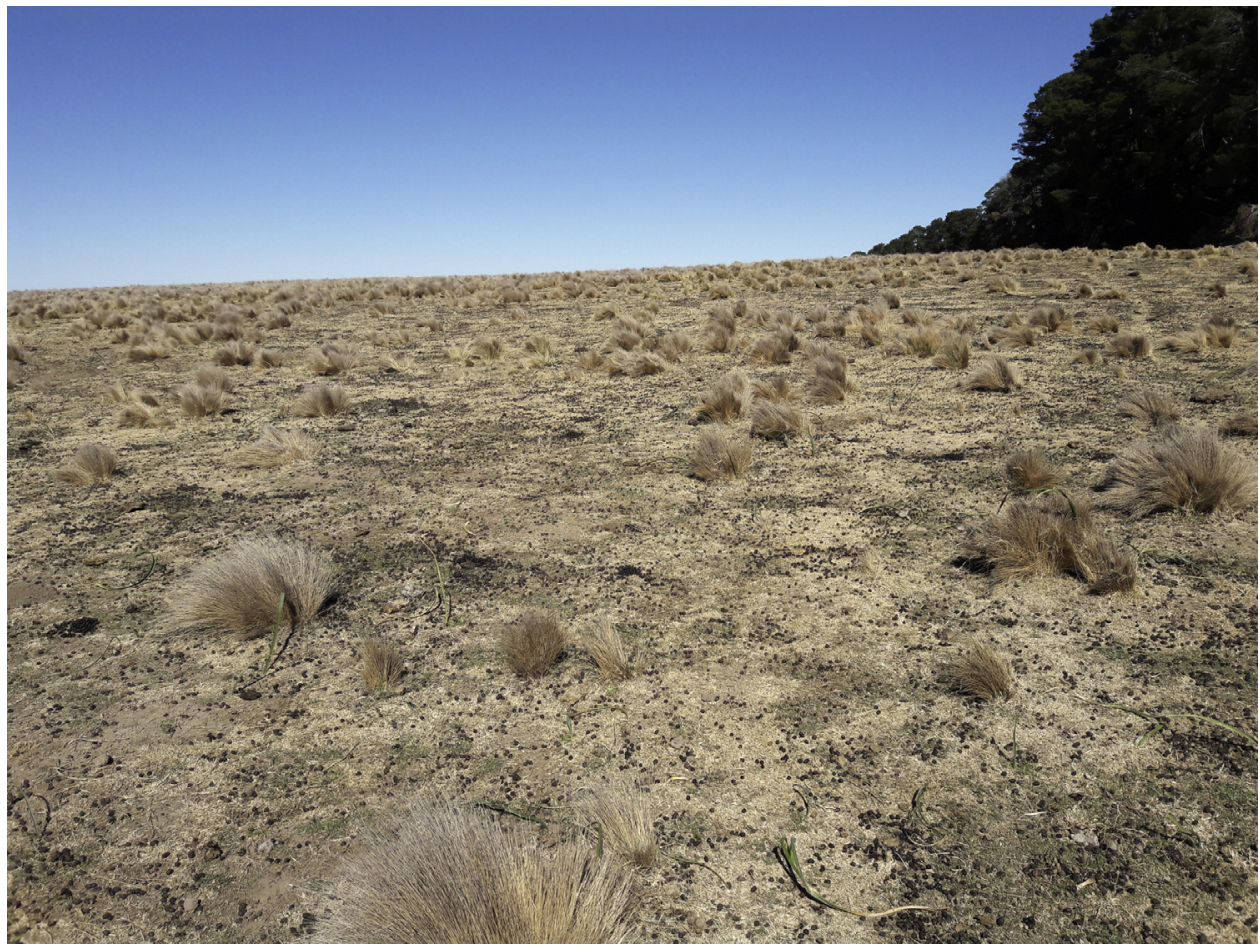

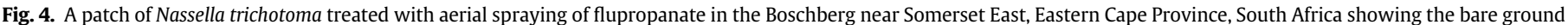
left as Nassella dies (Photo: A. Mapaura).

Because of the difficulty and poor performance of most conventional control methods, research into management systems that utilises Nassella but minimises its spread needs to be pursued (Grech et al., 2012). To counter and reduce incidences of chemical resistance, integrated approaches which utilise different chemicals for short periods coupled with mechanical and cultural methods would be desirable (Wells, 1977; Powells, 2018). A multi-faceted, multi-disciplinary Nassella control program involving biological,

Table 2

Potential and tested biocontrol agents against Nassella weeds.

\begin{tabular}{|c|c|c|c|}
\hline Biocontrol agent & Type of agent & Target Nassella species & Notes and References \\
\hline Alternaria sp. (Pleosporaceae) & Fungus & N. trichotoma & Not tested (McLaren and Cowan, 2012) \\
\hline Ascochyta leptospira var.variispora (Didymellaceae) & Bacteria & N. trichotoma & Potential (Briese and Evans, 1998; Hussaini et al., 2000) \\
\hline Corticiaceae sp. & Fungus & N. trichotoma & $\begin{array}{l}\text { Potential (Briese and Evans, 1998; Anderson et al., 2002; McLaren and } \\
\text { Anderson, 2011; McLaren and Cowan, 2012) }\end{array}$ \\
\hline Dinemasporium sp. (Chaetosphaeriaceae) & Fungus & N. trichotoma & Potential (Hussaini et al., 2000) \\
\hline Epicoccum sp. (Didymellaceae) & Fungus & N. trichotoma & Not host specific (McLaren and Cowan, 2012) \\
\hline Fusarium oxysporum (Nectriaceae) & Fungus & N. trichotoma & Not effective (Hussaini et al., 2000; McLaren and Cowan, 2012) \\
\hline Hendersonula sp. (Botryosphaeriaceae) & Fungus & N. trichotoma & Potential (Briese and Evans, 1998) \\
\hline Mucor sp. (Mucoraceae) & Fungus & N. trichotoma & Not tested (McLaren and Cowan, 2012) \\
\hline Paratrichodorus sp. (Trichodoridae) & Nematode & N. trichotoma & Not host specific (McLaren and Cowan, 2012) \\
\hline Phytophthora cryptogea (Pythiaceae) & Fungus & N. trichotoma & (McLaren and Cowan, 2012) \\
\hline Puccinia graminella (Pucciniaceae) & Fungus & N. neesiana & Not effective (Anderson et al., 2011, 2006) \\
\hline Puccinia nassellae (Pucciniaceae) & Fungus & N. neesiana, $N$. trichotoma & $\begin{array}{l}\text { Not host specific and not sufficiently pathogenic (Anderson et al., } \\
\text { 2002; Anderson et al., 2011, 2006; McLaren and Anderson, 2011; } \\
\text { McLaren and Cowan, 2012) }\end{array}$ \\
\hline Puccinia saltensis var. saltensis (Pucciniaceae) & Fungus & N. neesiana, $N$. tenuissima & Potential (Briese and Evans, 1998) \\
\hline Rhizoctonia sp. (Ceratobasidiaceae) & Fungus & N. trichotoma & Not tested (Briese and Evans, 1998; McLaren and Cowan, 2012) \\
\hline Rotylenchus sp. (Hoplolaimidae) & Nematode & N. trichotoma & Not host specific (McLaren and Cowan, 2012) \\
\hline Septoria sp. (Mycosphaerellaceae) & Fungus & N. trichotoma & Potential (Briese and Evans, 1998) \\
\hline Stagonospora sp. (Phaeosphaeriaceae) & Fungus & N. trichotoma & Potential (Briese and Evans, 1998) \\
\hline Tranzscheliella spp. (Ustilaginaceae) & Fungus & N. trichotoma N. neesiana & $\begin{array}{l}\text { Not sufficiently pathogenic (McLaren and Anderson, 2011; } \\
\text { McLaren and Cowan, 2012) }\end{array}$ \\
\hline Uredo sp. (incertae familiae) & Fungus & N. trichotoma & Potential (Briese and Evans, 1998) \\
\hline Uromyces pencanus (Pucciniaceae) & Fungus & N. neesiana & $\begin{array}{l}\text { Approved for release in New Zealand (on } 22 \text { June 2011) pending } \\
\text { export permit. Australia requires more host range tests before intro- } \\
\text { duction and release permit can be given. (Briese and Evans, 1998; } \\
\text { Anderson et al., 2006, 2010, 2011, 2017; Flemmer et al., 2010) }\end{array}$ \\
\hline Ustilago hypodytes (Ustilaginaceae) & Fungus & N. neesiana, $N$. trichotoma & Not specific (Briese and Evans, 1998) \\
\hline Ustilago sp. (Ustilaginaceae) & Fungus & N. trichotoma & More research needed (Briese and Evans, 1998; Anderson et al., 2002) \\
\hline
\end{tabular}


ecological, economic, social and legal issues will probably be the most effective (Anderson et al., 2003; Early et al., 2016).

\section{Climate change and projected future distribution}

The frequent droughts and extreme weather events such as cyclones and extreme temperatures being witnessed in southern Africa are the manifestation of climate change (Chersich and Wright, 2019). These weather events provide invasive plants with opportunities for dispersal and growth as native species can be negatively impacted (Masters and Norgrove, 2010). With frequent droughts, grazing pressure will remove good pasture species at a rate higher than recruitment which could favour non-palatable invasive species like Nassella (Faithfull, 2012; Grech et al., 2012; Morgan, 2001).

South Africa is in a unique situation in that the effects of climate change are taking place concurrently with socio-economic transformation coupled with rapid change in land use brought by majority rule (Richardson et al., 2000). The effects of climate change maybe more rapid and pronounced in such a situation than would otherwise be the case. This will have serious implications on species distribution and is of particular interest in the future control of invasive species such as Nassella. Global distribution models for N. neesiana and N. trichotoma have been done using CLIMEX models but not for $N$. tenuissima.

\subsection{Nassella neesiana}

Bourdôt et al. (2012), produced a CLIMEX model of the projected global distribution of $N$. neesiana. This model showed that the distribution will vary between countries and continents. In the Northern Hemisphere, suitable areas will generally expand with some current suitable areas becoming less suitable while in the Southern Hemisphere there is a general decline in suitable areas. In South Africa, suitable areas are expected to shrink marginally with the majority of the area remaining suitable. More importantly, $N$. neesiana has not yet saturated its current suitable area, and apparently currently occupies a small portion of it.

\subsection{Nassella trichotoma}

A model of suitable geographic range for $N$. trichotoma under current climate conditions indicates that there is great potential for expansion (Watt et al., 2011). An estimate of the global potential distribution under projected future climate change scenarios to 2080 , using CLIMEX showed a general increase in Europe and a decrease in the Southern Hemisphere. For South Africa, the projections show the suitable area marginally decreasing and Lesotho remaining optimal (Watt et al., 2011). The trend is that the lower reaches of the mountains will become unsuitable while areas higher up will remain suitable.

\section{Discussion}

Our review has highlighted the invasive nature, ecology and major impacts that Nassella invasions cause in terms of biodiversity, soil productivity, and the economy based on both local and foreign literature. Dense invasions of Nassella could lead to huge losses and costs to the animal husbandry industry, tourism, and severe impacts on biodiversity in the temperate montane grassland regions of South Africa. Globally, mountain areas are very important and contribute immensely to biodiversity and are already under pressure from population expansion and so cannot afford the threat from these invasive species (Rahbek et al., 2019). In South Africa, these mountains are home to many endemic, range-restricted and threatened species, and the continued expansion of these invasive grass species will likely contribute to their decline. The need to understand the status of these species in South Africa and to institute control measures is important and urgent.

A major problem is that Nassella species are difficult to differentiate from several native tussock species and from each other. It is very likely that some of the literature on $N$. trichotoma could actually be mistakenly referring to other Nassella species as very little information was found for the other two species. The available identification keys rely heavily on the presence of inflorescences. The problem is that when the inflorescence appears the seeds are mature, and it is too late to prevent propagation. Easy-to-use keys that do not rely heavily on inflorescences and which make it possible to identify the species before they flower are central prerequisites to the implementation of a successful control program (Taylor et al., 2016; Wang et al., 2016). The development of such a key, its distribution in areas susceptible to Nassella invasions, and training of stakeholders are crucial requirements.

The use of DNA techniques to distinguish similar species is rapidly becoming a reality. In South Africa, these techniques could be useful for separating the three Nassella species from any morphologically similar species. Sufficient phylogenetic distance exists among the three Nassella species (Cialdella et al., 2014) and it was demonstrated in a pilot study in Australia that N. neesiana and N. trichomata could be separated using the petL plastid gene (Wang et al., 2014). This gene needs to be sequenced in $N$. tenuissima as well. This would make it feasible to identify the species using these DNA markers.

The true extent of the current distribution and abundance of all three Nassella species in South Africa is not known. However, information gathered from stakeholders indicates that Nassella invasions have been increasing since the last published distribution records. The situation may be worse than currently thought considering that Nassella is highly mobile, especially the more invasive $N$. trichotoma. There is therefore an urgent need to determine the current distribution and densities of Nassella species in South Africa.

Chemical control has been the most widely used method and is considered the most effective way to keep Nassella invasions in check. The herbicides currently being used lack specificity, causing damage to desirable species in grassland and thus inadvertently giving Nassella species a competitive advantage. Also, the repeated use of flupropanate has led to chemical resistance in Australia. This development means research that integrates flupropanate into an integrated control strategy or reduces its use to a bare minimum might be required. The need for alternate integrated methods becomes even more compelling when it is considered that the chemicals on the market are not as target specific as initially thought even at the minimum recommended concentrations. This calls for more research into the best way to use these chemicals. For example, how often can spraying be repeated before it increases the possibility of resistance developing? What is the effect of environmental conditions such as rainfall, slope and wind on the efficacy of chemicals applied aerially? The possibility of incorporating adjuvants such as Citowett, Frigate and Reverseal 9 into herbicides, as suggested by Viljoen (1999), needs to be investigated.

Biological control research has highlighted a number of potential agents for invasive Nassella populations. Biocontrol offers a longterm and sustainable management option and can be used in concert with other control efforts. Uromyces pencanus, a rust fungus that has been approved in New Zealand for N. neesiana, can be tested using the standard procedures to verify its suitability for South Africa. Native range surveys also identified a number of agents that are specific to N. tenuissima and N. trichotoma that could be tested in South Africa.

With the predictions of climate change becoming a reality, information on the physiological responses of these invasive species to changing conditions is urgently needed. Models of currently suitable geographic areas show that Nassella species are far from saturating suitable areas. Most of these suitable areas are high mountainous 
areas, suggesting that the invasions could become a serious problem if no action is taken. Projecting into the future, existing models predict a decline in the suitable areas for Nassella in South Africa. The decline would likely be in the western fringes of the montane areas in the Eastern and Western Cape and the Free State provinces. To be able to effectively take action against Nassella invasion in South Africa, fine-scale predictions that take into account local variables are required. Such models could provide useful inputs to implementable coping strategies.

It is also important to understand the response of invasive species in relation to their co-occurring species especially as it pertains to their photosynthetic pathways. Nassella species $\left(C_{3}\right)$ have been recorded invading natural montane grasslands dominated by $T$. triandra $\left(\mathrm{C}_{4}\right)$ and Merxmuellera $\left(\mathrm{C}_{3}\right)$ (Faithfull, 2012; Clark and Vidal, 2019). Under the projected increase in temperature and atmospheric $\mathrm{CO}_{2}, \mathrm{C}_{3}$ plants are expected to become more vigorous while $C_{4}$ plants will have marginal responses since they are already operating at near maximum rate but the net gain of $C_{3}$ will be offset by the frequent droughts (Kriticos et al., 2010). The response of each specific species is affected by factors such as intra-specific and inter-species competition, herbivory pressure and management (Chen et al., 1996; Kriticos et al., 2010). These traits need to be included in species distribution models that seek to estimate responses of invasive species to climate change and hope to result in effective control programs (Chen et al., 1996).

\section{Conclusions}

The three Nassella species discussed in this paper are difficult to distinguish from each other and from other tussock grasses, especially when not flowering. This has had a significant effect on invasion detection and there is an urgent need for a new approach to collect more accurate distribution data. Identification guides that are accessible to non-scientists are required to encourage citizens to contribute data through platforms like iNaturalist. Current control efforts are uncoordinated and depend on the interest and the ability of individual property owners to fund control measures. As a result, efforts are failing to reduce existing invasions or prevent future spread. Invasive grasses have not generally been considered good targets for biological control however the prospects for Nassella species are promising and should be explored for South Africa. With climate change already a reality, models to predict future distribution ranges are needed to guide the prioritization of regions for management intervention.

\section{Declaration of Competing Interest}

The authors declare that they have no known competing financial interests or personal relationships that could have appeared to influence the work reported in this paper.

\section{Acknowledgements}

This research was financially supported by the Department of Science and Innovation-National Research Foundation (DSI-NRF), Centre of Excellences (CoE), Centre for Invasion Biology (CIB, Stellenbosch University), as well as the Afromontane Research Unit (ARU, University of the Free State). DMR specifically thanks the NRF (grant 85417) and the Oppenheimer Memorial Trust (grant 18576/03) for financial support to support this project through the CIB; KC thanks the Working for Water (WfW) programme of the Department of Environment, Forestry and Fisheries: National Resource Management (DEFF: NRM) programmes and the South African Research Chairs Initiative of the Department of Science and Technology (DST) and the National Research Foundation (NRF) for financial support to support this project through the CBC; AM thanks Rohan Kruger (Game Works Helicopters) for financial support for the project.

We thank David Currie, Dave Davenport, Danie and Phillip Erasmus, Gideon Gravenstein and Kitty and Richard Viljoen for providing valuable insights into the Nassella problems in the Eastern Cape Province and allowing access to their properties. Rohan Kruger (Game Works Helicopters) shared valuable insights on the spread and aerial control of Nassella trichotoma. Maryke Stern facilitated contact with farmers with invaded farms in the Eastern Cape. Sincere thanks are due to Lyn Fish and Aluoneswi Caroline Mashau for their assistance with aspects of identification and providing literature. Nicholas Le Maitre provided helpful insights on the potential use of DNA techniques for separating Nassella species.

\section{References}

Anderson, F., Pettit, W., Briese, D.T., McLaren, D.A., 2002. Biological control of serrated tussock and Chilean needlegrass. Plant Protection Quarterly 17, 104-111.

Anderson, F.E., Barton, J., McLaren, D., 2010. Studies to assess the suitability of Uromyces pencanus as a biological control agent for Nassella neesiana (Poaceae) in Australia and New Zealand. Australasian Plant Pathology 39, 69-78. https://doi.org/ 10.1071/AP09057.

Anderson, F.E, Díaz, M.L., Barton, J., Flemmer, A.C., Hansen, P.V., McLaren, D.A., 2011. Exploring the life cycles of three South American rusts that have potential as biocontrol agents of the stipoid grass Nassella neesiana in Australasia. Fungal Biology 115 (4-5), 370-380. https://doi.org/10.1016/j.funbio.2011.01.008.

Anderson, F.E., Díaz, M.L., McLaren, D.A., 2006. Current status of research on potential biological control agents for Nassella neesiana and Nassella trichotoma (Poaceae) in Australia. In: Preston, C, Watts, JH, Crossman, ND (Eds.), Proceedings of the Fifteenth Australian Weeds Conference. Adelaide, South Australia. Weed Management Society of South Australia, pp. 591-594.

Anderson, F.E., Gallego, L., Sánchez, R.M., Flemmer, A.C., Hansen, P.V., McLaren, D., Barton, J., 2017. Plant/pathogen interactions observed during host range testing of the rust fungus Uromyces pencanus, a classical biological control agent for Chilean needle grass (Nassella neesiana) in Australia and New Zealand. Biocontrol Science and Technology 27 (9), 1096-1117. https://doi.org/10.1080/ 09583157.2017.1384795.

Anderson, G.L., Delfosse, E.S., Spencer, N.R., Prosser, C.W., Richard, R.D., 2003. Lessons in developing successful invasive weed control programs. Rangeland Ecology and Management / Journal of Range Management Archives 56 (1), 2-12.

Badgery, W.B., 2004. Managing competition between Nassella trichotoma (serrated tussock) and native grasses. PhD thesis The University of Sydney.

Badgery, W., Kemp, D.K., MIchalk, D.L., King, W.M.C.G., 2005. Competition for nitrogen between Australian native grasses and the introduced weed Nassella trichotoma. Annals of Botany 96, 799-809. https://doi.org/10.1093/aob/mci230.

Badgery, W.B., Kemp, D.R., Michalk, D.L., King, W.M., 2008. Studies of competition between Nassella trichotoma (Nees) Hack. ex Arechav. (serrated tussock) and native pastures. 2. Seedling responses. Australian Journal of Agricultural Research 59, 237-246.

Barkworth, M., Arriaga, M., Smith, J., Jacobs, S., Valdés-Reyna, J., Bushman, B., 2008. Molecules and morphology in South American Stipeae (Poaceae). Systematic Botany 33 (4), 719-731. https://doi.org/10.1600/036364408786500235.

Barkworth, M., Torres, M., 2001. Distribution and diagnostic characters of Nassella (Poaceae: Stipeae). Taxon 50 (2 part 4), 439-468. https://doi.org/10.2307/ 1223891.

Bläßet, C., Ronnenberg, K., Tackenberg, O., Hensen, I., Wesche, K., 2010. The relative importance of different seed dispersal modes in dry Mongolian rangelands. Journal of Arid Environments 74, 991-997. https://doi.org/10.1016/j.jaridenv.2009.12.002.

Bourdôt, G., Basse, B., Kriticos, D., Dodd, M., 2015. Cost-benefit analysis blueprint for regional weed management: Nassella neesiana (Chilean needle grass) as a case study. New Zealand Journal of Agricultural Research 58 (3), 325-338. https://doi. org/10.1080/00288233.2015.1037460.

Bourdôt, G.W., Hurrell, G.A., 1992. Aspects of the ecology of Stipa neesiana Trin. and Rupr. seeds. New Zealand Journal of Agricultural Research 35 (1), 101-108. https:// doi.org/10.1080/00288233.1992.10417707.

Bourdôt, G.W., Hurrell, G.A., Saville, D.J., 1992. Eradication of nassella tussock (Nassella trichotoma), an unlikely outcome of grubbing. New Zealand Journal of Agricultural Research 35 (3), 245-252. https://doi.org/10.1080/00288233.1992.10427501.

Bourdôt, G.W., Jackman, S., Saville, D.J., 2017. Plant mortality and seedling recruitment responses to flupropanate in grassland populations of Nassella trichotoma. New Zealand Plant Protection 70, 160-164. https://doi.org/10.30843/nzpp.2017.70.42.

Bourdôt, G.W., Lamoureaux, S.L., Watt, M.S., Manning, L.K., Kriticos, D.J., 2012. The potential global distribution of the invasive weed Nassella neesiana under current and future climates. Biol Invasions 14 (8), 1545-1556. https://doi.org/10.1007/ s10530-010-9905-6.

Bourdôt, G.W., Saville, D.J., 2019. Nassella trichotoma - plant growth rates and effects of timing of grubbing on populations in North Canterbury grassland. New Zealand Journal of Agricultural Research 62 (2), 224-245. https://doi.org/10.1080/ 00288233.2018.1483954.

Briese, D.T., Evans, H.C., 1998. Biological control of serrated tussock (Nassella trichotoma): is it worth pursuing? Plant Protection Quarterly 13 (2), 94-97. 
Briese, D.T., McLaren, D.A., Pettit, W.J., Zapater, M., Anderson, F., Delhey, R., Distel, R., 2000. New biological control initiatives against weeds of South American origin in Australia: Nassella tussock grasses and blue heliotrope. In: Spencer, NR (Ed.), Proceedings of the Tenth International Symposium on Biological Control of Weeds. Montana State University, Bozeman., Montana, USA, pp. 215-223.

Campbell, M.H., 1982. The biology of Australian weeds. 9: Nassella trichotoma (Nees) Arech. Journal of the Australian Institute of Agricultural Science 48 (2), 76-84.

Campbell, M.H., 1998. Biological and ecological impact of serrated tussock (Nassella trichotoma (Nees) Arech.) on pastures in Australia. Australia: Plant Protection. Plant Protection Quarterly ReportNo. 13 (2).

Campbell, M.H., Ridings, H.I., 1988. Tolerance of grazed and ungrazed Phalaris aquatica to glyphosate, tetrapion and 2,2-DPA. Australian Journal of Experimental Agriculture 28, 747-751.

Campbell, M.H., Van de Van, R., 1996. Tolerance of native grasses to Frenock ${ }^{\circledR}$ and Round up ${ }^{\circledast}$. In: Proceedings of the Eleventh Annual Conference of the Grassland Society of NSW. Grassland Society of NSW, pp. 120-121.

Chersich, M.F., Wright, C.Y., 2019. Climate change adaptation in South Africa: a case study on the role of the health sector. Global Health 15, 22. https://doi.org/ 10.1186/s12992-019-0466-X.

Chen, D., Hunt, H.W., Morgan, J.A., 1996. Responses of a $C_{3}$ and $C_{4}$ perennial grass to $\mathrm{CO}_{2}$ enrichment and climate change: comparison between model predictions and experimental data. Ecological Modelling 87, 11-27.

Cialdella, A.M., Sede, S.M., Romaschenko, K., Peterson, P.M., Soreng, R.J., Zuloaga, F.O., Morrone, O., 2014. Phylogeny of Nassella (Stipeae, Pooideae, Poaceae) based on analyses of chloroplast and nuclear ribosomal DNA and morphology. Systematic Botany 39 (3), 1-15. https://doi.org/10.1600/036364414X681419.

Clark, V.R., Vidal, J.D., 2019. The vegetation of Asante Sana Private Game Reserve and surrounds, Sneeuberg Centre of Floristic Endemism (Eastern Cape Province, South Africa). Esperiana Memoir 8, 25-38.

Connor, H.E., Edgar, E., Bourdôt, G.W., 1993. Ecology and distribution of naturalised species of Stipa in New Zealand. New Zealand Journal of Agricultural Research 36 (3), 301-307.

Conolly, J., Taylor, S., 2016. Mexican feather grass (Nassella tenuissima) control - the ACT experience. In: Randall, R., Lloyd, S., Borger, C. (Eds.), Proceedings of the Twentieth Australasian Weeds Conference. Perth. Weeds Society of Western Australia, pp. 228-231.

Cooperative Research Centres, 2003. Alert list for environmental weed. Weed Management Guide: Chilean Needle Grass - Nassella neesiana. Australian Pamplet. Weed Management and the Commonwealth Department of the Environment and Heritage.

Dickens, S.J.M., Allen, E.B., 2014. Exotic plant invasion alters chaparral ecosystem resistance and resilience pre- and post-wildfire. Biological Invasions 16 (5), 1119-1130. https://doi.org/10.1007/s10530-013-0566-0.

Early, R., Bradley, B.A., Dukes, J.S., Lawler, J.J., Olden, J.D., Blumenthal, D.M., Gonzalez, P., Grosholz, E.D., Ibanez, I., Miller, L.P., et al., 2016. Global threats from invasive alien species in the twenty-first century and national response capacities. Nature Communications 7 (12485), 1-9.

Cook, C., 1998. The transmission of serrated tussock (Nassella trichotoma) seeds through the sheep rumen and their viability after ingestion. Report No. 13 (2).

Erb, H.E., 1988. Stipa trichotoma: Some considerations on the species, its habitat and natural distribution in Argentina. Report for the Department of Nature and Environmental Conservation of the Cape Provincial Administration. Cape Town. South Africa.

Evans, H., 1991. In: Baker, FWG, Terry, PJ (Eds.), CAB International, Wallingford. Tropical grassy weeds.

Faithfull, I.G., 2012. Biodiversity impacts of Chilean needle grass, Nassella neesiana to Australia's indigenous grasslands [PhD]. Victoria University of Technology, Australia.

Faithfull, I.G., Hocking, C., McLaren, D.A., 2012. In: Eldershaw, V (Ed.), Weed Society of Victoria Inc, Melbourne, Victoria, Australia. Available at http://www.caws.org.au/ awc/2012/awc201210591.pdf. Accessed 2012 Oct 8.

Fish, L., Mashau, A.C., Moeaha, M.J., Nembudani, M.T., 2015. Identification Guide to Southern African Grasses: An Identification Manual with Keys, Descriptions, and Distributions, 36. SANBI, Pretoria. Strelitzia.

Flemmer, A.C., Anderson, F.E., Hansen, P.V., McLaren, D.A., 2010. Microscopic observations of a compatible host/pathogen interaction between a potential biocontrol agent (Uromyces pencanus) and its target weed (Nassella neesiana). Mycoscience 51 (5), 396-400. https://doi.org/10.1007/S10267-010-0051-X.

Global Invasive Species Database (GISD). 2019. Apr 18. Species profile Nassella tenuissima. Available at http://www.iucngisd.org/gisd/species.php?sc=463. Accessed 8 October 2018.

Germishuizen, G., Meyer, N.L., NBI, 2003. Plants of Southern Africa: An Annotated Checklist. National Botanical Institute, Pretoria, South Africa.

Grech, C.J., McLaren, D.A., Lowien, J., McWhirter, L., Butler, K.L., Sindel, B.M., 2012. Assessment of management options for Chilean needle grass in sheep-grazing systems. Grass and Forage Science 69, 119-128.

Grech, C.J., McLaren, D.A., Lowien, J., McWhirter, L., Butler, K.L., Sindel, B.M., 2014. Effects of flupropanate application on bare ground and broadleaf weeds when used to control Chilean needle grass in introduced pastures. New Zealand Journal of Agricultural Research 57 (2), 100-109. https://doi.org/10.1080/ 00288233.2014.886597.

Hanley, N., Roberts, M., 2019. The economic benefits of invasive species management. People and Nature 1 (2), 124-137. https://doi.org/10.1002/pan3.31.

Healy, A.J., 1945. Nassella tussock (Nassella trichotoma (Nees.) Hack.). Field studies and their agricultural significance. Department of Science and Industrial Research(22), 1-90 Bulletin No. 91.
Henderson, L., 2001. Alien Weeds and Invasive Plants: A Complete Guide to Declared Weeds and Invaders in South Africa. Agricultural Research Council, Pretoria, South Africa. Plant Protection Research Institute Handbook no. 12

Henderson, L., 2007. Invasive, naturalized and casual alien plants in southern Africa: a summary based on the Southern African Plant Invaders Atlas (SAPIA). Bothalia 37 (2), 215-248.

Henderson, L., 2018. Shocking Nassella Invasion Threatens South Africa's Mountain Grasslands. ARC-Plant Protection Research Institute, Pretoria. SAPIA News Report No.: 48 .

Henderson, L., Wilson, J.R.U., 2017. Changes in the composition and distribution of alien plants in South Africa : an update from the Southern African Plant Invaders Atlas. Bothalia - African Biodiversity and Conservation 47 (2), 1-26. https://doi. org/10.4102/abc.v47i2.2172.

Howell, C.J., Sawyer, J.W.D., 2006. New Zealand Naturalised Vascular Plant Checklist. Plant Conservation Network, Wellington: New Zealand.

Hussaini, I.P., Lawrie, A.C., McLaren, D.A., 2000. Pathogens on and variation in Nassella trichotoma (Poales: Poaceae) in Australia. In: Spencer, N.R. (Ed.), Proceedings of the Tenth International Symposium on Biological Control of Weeds. Montana, USA. Bozeman, Montana State University, Montana, USA, pp. 269-280.

Jacobs, S.W.L., Everett, J., Torres, M.A., 1998. Nassella tenuissima (Gramineae) recorded from Australia, a potential new weed related to serrated tussock. Telopea 8 (1), 41-46.

Jones, R.E., Vere, D.T., Campbell, M.H., 2000. The external costs of pasture weed spread: an economic assessment of serrated tussock control. Agricultural Economics 22 (1), 91-103.

Joubert, D.C., 1984. The soil seed bank under nassella tussock infestations at Boschberg. South African Journal of Plant and Soil 1 (1), 1-3.

Kriticos, D.J., Crossman, N.D., Ota, N., Scott, J.K., 2010. Climate Change and Invasive Plants in South Australia. CSIRO Climate Adaptation Flagshi, Canberra, Australia. p.

Lamoureaux, S., Bourdôt, G.W., 2002. Fruit viability on grubbed Nassella trichotoma (Nees) tussocks. Australian Journal of Experimental Agriculture 42, 1057-1061. https://doi.org/10.1071/ea02032.

Lamoureaux, S., Bourdôt, G.W., Verkaaik, M., 2006. Outsmarting nassella tussock answers to often-asked questions based on recent research findings. In: Preston, $\mathrm{C}$ Watts, JH, Crossman, ND (Eds.), Proceedings of the Fifteenth Australian Weeds Conference; Adelaide, Australia. Weed Management Society of South Australia.

Lusk, C.S., Hurrell, G.A., Saville, D.J., Bourdôt, G.W., 2017. Changes in plant species composition after flupropanate application for nassella tussock control, in Canterbury hill-country pastures. New Zealand Journal of Agricultural Research 60 (3), 263276. https://doi.org/10.1080/00288233.2017.1321556.

Masters, G., Norgrove, L., 2010. Climate change and invasive alien species. CABI Working Paper, pp. 1-30.

McLaren, D., Anderson, F.E.., 2011. Protecting Australia's Agricultural Grasslands from Herbicide-Resistant Serrated Tussock. RIRDC Publication.. Report No.: Pub. No. 11/ 070. Available at https://www.agrifutures.com.au/product/protecting-australia-sagricultural-grasslands-from-herbicide-resistant-serrated-tussock/. Accessed 8 Oct 2019.

McLaren, D., Cowan, R., 2012. Biological control of serrated tussock. North Sydney: Meat and Livestock Australia Limited. Report No.: Final Report.

McLaren, D.A., Anderson, F.E., 2011. Biological Control of Serrated Tussock and Chilean Needle Grass. Rural Industries Research and Development Corporation, Canberra, Australia. Report No.: Pub. No. 11/040.

McLaren, D.A., Snell, K., Butler, K.L., 2008. An assessment of native tree susceptibility to the simulated aerial application of the herbicide flupropanate, for management of exotic unpalatable grasses. In: van Klinken, RD, Osten, VA, Panetta, FD, Scanlan, JC (Eds.), Hot Topics in the Tropics. Queensland Weeds Society, Queensland, Australia.

McLaren, D.A., Stajsic, V., Gardener, M.R., 1998. The distribution and impact of South/ North American stipoid grasses (Poaceae: Stipeae) in Australia. Plant Protection Quarterly 13 (2), 62-70.

McLaren, D.A., Stajsic, V., Iaconis, L., 2004. The distribution, impacts and identification of exotic stipoid grasses in Australia. Plant Protection Quarterly 19 (2), 59-66.

Miller, L., 1998. Management of serrated tussock in farming areas. Plant Protection Quarterly 13 (2), 91-93.

Milton, S.J., 2004. Grasses as invasive alien plants in South Africa. South African Journal of Science 100, 69-75.

Moretto, A.S., Distel, R.A., 1998. Requirement of vegetation gaps for seedling establishment of two unpalatable grasses in a native grassland of central Argentina. Australian Journal of Ecology 23, 419-423.

Morgan, J.W., 2001. Seedling recruitment patterns over 4 years in an Australian perennial grassland community with different fire histories. Journal of Ecology 89, 908919. https://doi.org/10.1111/j.1365-2745.2001.00617.x.

Nkuna, K.V., Visser, V., Wilson, J.R.U., Kumschick, S., 2018. Global environmental and socio-economic impacts of selected alien grasses as a basis for ranking threats to South Africa. NB 41, 19-65. https://doi.org/10.3897/neobiota.41.26599.

Occdownload Gbif.Org, 2019. GBIF occurrence download-Nassella tenuissima. The Global Biodiversity Information Facility. https://doi.org/10.15468/DL.YPBDSK.

Powells, J., 2018. Flupropanate resistant serrated tussock (Nassella trichotoma) identified at multiple locations in the Monaro, New South Wales. In: Johnson, S, Weston L, Wu, H, Auld, B (Eds.), Proceedings of the Twentyfirst Australasian Weeds Conference. The Weed Society of New South Wales Inc, p. 397.

Pyšek, P., Pergl, J., van Kleunen, M., et al., 2020. South Africa as a donor of naturalized and invasive plants to other parts of the world. In: van Wilgen, BW, Measey, J Richardson, DM, Wilson, JR, Zengeya, TA (Eds.), Biological Invasions in South Africa. Springer, Berlin, pp. 755-782. doi.org/10.1007/978-3-030-32394-3_26. 
Pyšek, P., Richardson, D.M., Rejmánek, M., Webster, G.L., Williamson, M., Kirschner, J., 2004. Alien plants in checklists and floras: towards better communication between taxonomists and ecologists. Taxon 53,131-143. https://doi.org/10.2307/4135498.

Quattrocchi, U., 2000. CRC World Dictionary of Plant Names: Common Names, Scientific Names, Eponyms, Synonyms, and Etymology. Vol. 3: M - Q. CRC Press, Boca Raton, FL.

Rahbek, C., Borregaard, M.K., Colwell, R.K., Dalsgaard, B., Holt, B.G., Morueta-Holme, N., Nogues-Bravo, D., Whittaker, R.J., Fjeldsă, J., 2019. Humboldt's enigma: what causes global patterns of mountain biodiversity? Science 365 (6458), 1108-1113. https://doi.org/10.1126/science.aax0149.

Ranwashe, P., 2019. BODATSA: Botanical Collections v1.4. South African National Biodiversity Institute. Dataset/Occurrence. Available at http://ipt.sanbi.org.za/iptsanbi/ resource? r=brahms online\&v=1.4. Accessed 27 July 2019.

Richardson, D.M., Bond, W.J., Dean, W.R.J., Higgins, A.I., Midgley, G., Milton, S.J., 2000. Invasive alien species and global change: a South African perspective. In: Mooney, HA, Hobbs, RJ (Eds.), Invasive Species in a Changing World. Island Press, Washington, DC, pp. 303-350.

Richardson, D.M., Foxcroft, L.C., Latombe, G., Le Maitre, D.C., Rouget, M., Wilson, J.R.U., 2020. The biogeography of South African terrestrial plant invasions. In: Van Wilgen, BW, Measey, J, Richardson, DM, Wilson, JRU, Zengeya, T (Eds.), Biological Invasions in South Africa. Springer, Berlin. in press.

Richardson, D.M., Wilson, J.R.U., Weyl, O.L.F., Griffiths, C.L., 2011. South Africa: Invasions. In: Simberloff, D, Rejmánek, M (Eds.), Encyclopedia of Biological Invasions. University of California Press, Berkeley, pp. 643-651.

Romaschenko, K., Peterson, P., Soreng, R., Garcia-Jacas, N., Futorna, O., Susanna, A., 2012. Systematics and evolution of the needle grasses (Poaceae: Pooideae: Stipeae) based on analysis of multiple chloroplast loci, ITS, and lemma micromorphology. Taxon 61, 18-44. https://doi.org/10.1002/tax.611002.

Romaschenko, K., Peterson, P.M., Soreng, R.J., Garcia-Jacas, N., Futorna, O., Susanna, A., 2008. Molecular phylogenetic analysis of the American Stipeae (Poaceae) resolves Jarava sensu lato polyphyletic: evidence for a new genus. Pappostipa. Journal of the Botanical Research Institute of Texas 2 (1), 165-192.

Smith, L.P., Lamoureaux, S.L., 2006. When science meets policy - nassella tussock in New Zealand as a case study. In: Proceedings of the Fifteenth Australian Weeds Conference proceedings. Weed Management Society of SA, pp. 450-453.

Soreng, R., Peterson, P., Davidse, G., Judziewicz, E., Zuloaga, F., Filgueiras, T.S., Morrone, O., 2009. Tropicos - name search. Available at http://www.tropicos.org/NameSearch.aspx. Accessed 8 May 2019.

Sutton, G.F., Canavan, K., Day, M.D., den Breeyen, A., Goolsby, J.A., Cristofaro, M., McConnachie, A., Paterson, I.D., 2019. Grasses as suitable targets for classical weed biological control. BioControl 64, 605-622. https://doi.org/10.1007/s10526-01909968-8.

Taylor, N.J., 1987. Ecological aspects of nassella tussock (Stipa trichotoma). Botany Division, Lincoln, New Zealand. DSR.

Taylor, S., Conolly, J., Gruber, A., 2016. Chilean needle grass (Nassella neesiana) control - the ACT experience. In: Randall, R, Lloyd, S, Borger, C (Eds.), Proceedings of the Twentieth Australasian Weeds Conference. Perth. Weeds Society of Western Australia, pp. 223-227.

Vere, D.T., Campbell, M.H., 1984. Economics of controlling serrated tussock in the southeastern Australian rangelands. Journal of Range Management 37 (1), 87-93.
Verloove, F., 2005. A synopsis of Jarava Ruiz and Pav. and Nassella E. Desv. (Stipa L. s.l.) (Poaceae: Stipeae) in southwestern Europe. Candollea 60 (1), 97-117.

Viljoen, B.D., 1987. Effect of rate and time of application of tetrapion on nassella tussock (Stipa trichotoma Nees) in South Africa. South African Journal of Plant and Soil 4 (2), 79-81.

Viljoen, B.D. 1999. Influence of adjuvants on tetrapion efficacy for nassella tussock (Stipa trichotoma Nees) control and subsequent seedling establishment: a preliminary study. South African Journal of Plant and Soil 16 (2), 102-105. https://doi.org/ 10.1080/02571862.1999.10634855.

Visser, V., Wilson, J.R.U., Canavan, K., Canavan, S., Fish, L., Le Maitre, D., Nänni, I., Mashau, C., O'Connor, T., Ivey, P., et al., 2017. Grasses as invasive plants in South Africa revisited: Patterns, pathways and management. Bothalia 47 (2), 29. https:// doi.org/10.4102/abc.v47i2.2169 pages.

Visser, V., Wilson, J.R.U., Fish, L., Brown, C., Cook, G.D., Richardson, D.M., 2016. Much more give than take: South Africa as a major donor but infrequent recipient of invasive non-native grasses. Global Ecology and Biogeography 25, 679-692. https://doi.org/10.1111/geb.12445.

Wang, A., Gopurenko, D., Wu, H., Stanton, R., Lepschi, B.J., 2014. DNA barcoding for identification of exotic grass species present in eastern Australia. In: Baker, M (Ed.), Proceedings of the Nineteenth Australasian Weeds Conference (2014). Tasmanian Weed Society, pp. 444-447.

Wang, A., Wu, H., Gopurenko, D., 2016. Chloroplast genome of serrated tussock (Nassella trichotoma): structure and evolution. In: Randall, R, Lloyd, S, Borger, C (Eds.), Proceedings of the Twentieth Australasian Weeds Conference. Perth. Weeds Society of Western Australia, pp. 152-156.

Watt, M.S., Kriticos, D.J., Lamoureaux, S.L., Bourdôt, G.W., 2011. Climate change and the potential global distribution of serrated tussock (Nassella trichotoma). Weed Science 59 (4), 538-545. https://doi.org/10.1614/WS-D-11-00032.1.

Weller, S.L., Florentine, S.K., Sillitoe, J.F., Grech, C.J., McLaren, D.A., 2016. An investigation of the effects of stage of ensilage on Nassella neesiana seeds, for reducing seed viability and injury to livestock. Scientific Report 6 (22345), 1-7. https://doi.org/ $10.1038 /$ srep22345.

Weller, S.L., Florentine, S., Sillitoe, J.F., Grech, C., McLaren, D., Chauhan, B.S., 2016. Detecting the Seeds of Nassella neesiana in Large Round Hay Bales, by Means of Non-Destructive Core Sampling. PLoS One 10 (9), 1-15. https://doi.org/10.1371/ journal.pone.0137343.

Wells, M.J., 1977. Progress with research on Nassella tussock. In: Proceedings of the Second National Weeds Conference of South Africa. Stellenbosch, Cape Town. Stellenbosch, Cape Town, South Africa, pp. 47-55.

Wells, M.J., 1978. Nassella tussock. In: Stirton, CH (Ed.), Plant Invaders: Beautiful but Dangerous. Department of Nature and Environmental Conservation of the Cape Provincial Administration, Cape Town, South Africa, pp. 140-143.

Wells, M.J., De Beer, H., 1987. Nassella Tussock. Agricultural Research Council. Weeds A.21/1987.

Wells, M.J., Engelbrecht, V.M., Balsinhas, A.A., Stirton, C.H., 1983. Weed flora of South Africa 2: power shifts in the veld. Bothalia $14(3 / 4), 961-965$.

Westbrooks, R.G., Cross, G., 1993. Serrated Tussock (Nassella trichotoma) in the United States. Weed Technology 7 (2), 525-528.

Taskforceherbicide, 2020. TASKFORCE ${ }^{\circledR}$ herbicide: frequently asked questions. Available at: http://taskforceherbicide.com/faq. Accessed 24 Jan 2020. 